\title{
En kvinne i 50-årene med manisk psykose
}

\author{
En kvinne som ble tvangsinnlagt for manisk psykose viste seg å trenge \\ en helt annen behandling enn først antatt.
}

Se kommentar side 539

Engelsk oversettelse på www.tidsskriftet.no

\section{Adrian Razvan Pasareanu}

Distriktspsykiatrisk senter Solvang

Sørlandet sykehus

\section{Åse Mygland \\ Nevrologisk avdeling}

og

Avdeling for voksenhabilitering

Sørlandet sykehus Kristiansand

og

Institutt for klinisk medisin

Universitetet i Bergen

\section{Øistein Kristensen}

oistein.kristensen@sshf.no

Avdeling for rus og avhengighetsbehandling

Sørlandet sykehus Kristiansand

En kvinne i slutten av 50-årene uten tidligere psykisk lidelse ble innlagt akutt i psykiatrisk avdeling til tvungen observasjon fordi hun ble oppfattet som psykotisk av legevaktlegen. Hun hadde vært på hytta sammen med mannen sin i noen uker og var de siste to dagene blitt tiltakende urolig og rastløs, med høylytt usammenhengende tale og lite søvn.

Ved innleggelsen i psykiatrisk avdeling var hun orientert for tid, sted og situasjon. Hun hadde taleflom, hevet stemningsleie og økt motorisk tempo. Det var ikke tegn til hallusinose eller tydelige brister $i$ tankegangen. $\mathrm{Pa}$ sienten var tidligere frisk, bortsett fra en kjent velbehandlet hypertensjon. Ved innkomsten klaget hun over vage smerter i skulder og nakke som var vanskelig å få beskrevet presist. Temperatur og blodprøver var normale. Siden det dreide seg om en førstegangs psykose ble CT caput rekvirert, og denne var negativ.

Med fysisk rastløshet, nedsatt søvnbehov, taleflom og hevet stemningsleie som krevde hospitalisering, oppfylte pasienten de diagnostiske kriteriene for akutt mani (tab 1) (1). På grunn av akutt debut var delirium (konfusjon) en mulig differensialdiagnose, men den ble vurdert som lite sannsynlig fordi hun var orientert for tid, sted og situasjon, og verken bevissthetsinnhold eller bevissthetsnivå var endret. Det forelå heller ingen deliriumdisponerende faktorer som feber, metabolsk forstyrrelse, medikament/alkoholmisbruk eller demens. Smerter i nakke og skulder ble ikke vektlagt på dette tidspunktet.

Pasienten ble behandlet $i$ to døgn med Sobril $25 \mathrm{mg} \times 3$ og Seroquel $50 \mathrm{mg}+150 \mathrm{mg}$ per døgn for mani, men dette hadde bare moderat effekt. Hun klaget etter hvert over sterke smerter i nakken og skuldermuskulaturen og ble mer ustø og sjanglete i gangen.

Moderat effekt av medisiner, pasientens alder, smerter og nevrologiske symptomer i form av ustøhet og svekket gangfunksjon førte til at man mistenkte at pasientens mani var sekundær til en nevrologisk sykdom. Etter nevrologisk tilsyn ble hun derfor overflyttet til nevrologisk avdeling for videre utredning, to døgn etter ankomsten.

Ved innleggelse i nevrologisk avdeling oppga pasienten å ha nakkesmerter. Ved klinisk undersøkelse ble det funnet redusert kraft $i$ høyre hånd og spent nakkemuskulatur. Det var ingen nakkestivhet eller feber. Blodprøver, CT caput og røntgenbilder av skulder og nakke var normale. Det ble gjort spinalpunksjon, og cerebrospinalvæsken var patologisk med forhøyet celletall 351 leukocytter per $\mathrm{mm}^{3}$ (referanseområde $\leq 4$ ), og protein 1,60 g/l (referanseområde 0,10-0,40). Hun kunne ikke huske å ha hatt flåttbitt eller erythema migrans-liknende utslett.

Nakkesmerter, redusert kraft i høyre hånd og cerebrale symptomer i form av mani ledsaget av forhøyet celletall i spinalvæsken ga mistanke om kombinert meningoradikulitt og encefalitt, mest sannsynlig forårsaket av virus eller borreliainfeksjon (nevroborreliose). Andre mulige årsaker som purulent bakterieinfeksjon eller autoimmun sykom/ vaskulitt ble regnet som mindre sannsynlig på grunn av manglende systemiske infeksjonstegn, mononukleært utseende på leukocyttene og normale blodprøver.

Det ble startet behandling for meningoencefalitt med intravenøs aciklovir (750 mg $\times 3$ ) og ceftriakson $(2 g \times 1)$ pga. mistanke om virus eller borreliainfeksjon. Symptomene avtok betydelig i løpet av et par dager. Etter tre dager viste det seg at polymerasekjedereaksjonstest (PCR) for herpes simplex i spinalvæske var negativ, og aciklovir ble seponert. Borreliaantistoffanalyser viste forhøyet nivå $i$ serum (lgM var påvist, men ikke kvantitert og IgG var $144 \mathrm{mg} / \mathrm{ll}$, men det var normal ratio mellom nivå $i$ serum og cerebrospinalvæsken (negativ borreliaantistoffindeks). Behandlingen med ceftriakson ble fortsatt. Cerebrospinalvæskeundersøkelse etter seks dager viste nedgang $i$ antall leukocytter til 185 per $\mathrm{mm}^{3}$, men -antistoffindeksen var fortsatt negativ. Hun ble utskrevet i velbefinnende etter 14 dagers ceftriaksonbehandling med diagnosen sannsynlig nevroborreliose. Det ble ikke gjort avtale om kontroll.

Etter to måneder ble hun reinnlagt pga. tretthet og mistanke om residiv. Hun hadde da normal nevrologisk og psykiatrisk status. Celletallet $i$ cerebrospinalvæsken var normalt, men borreliaantistoffindeks var blitt positiv. Disse funnene avkreftet mistanken om residiv av encefalitt, men bekreftet at hun hadde gjennomgått nevroborreliose. Trettheten ble vurdert som en naturlig følgetilstand etter gjennomgått encefalitt kombinert med stor arbeidsbelastning. Hun ble utskrevet uten spesifikk behandling med informasjon om forventet gradvis bedring av

Tabell 1 Diagnostiske kriterier for mani (ICD-10). For at diagnosen skal kunne stilles, må A pluss minst tre B-symptomer være til stede

A. Hevet, ekspansivt eller irritabelt stemningsleie i minst en uke eller at vedkommende er hospitaliseringskrevende

B. Minst tre av følgende symptomer (fire hvis kun irritabelt stemningsleie)

a. Økt aktivitet/fysisk rastløshet

b. Mer pratsomhet

c. Idéflukt eller en subjektiv opplevelse av at tankene raser av sted

d. Tap av vanlige sosiale hemninger med upassende atferd som følger

e. Nedsatt behov for $\varsigma \varnothing v n$

f. Sterkt forøket selvfølelse eller storhetsforestilling

g. Distraherbarhet eller stadig forandring av planer eller aktivitet

h. Risikopreget eller uvøren atferd

i. Markert økt seksuell energi eller ukritisk seksuell atferd 
Tabell 2 Somatiske årsaker til sekundær mani (modifisert fra (6))

\begin{tabular}{|c|c|c|c|}
\hline Medikamenter & Rusmidler & Metabolske forstyrrelser & Nevrologisk sykdom \\
\hline Anabole steroider & Alkohol & Anemi & $\begin{array}{l}\text { Cerebrovaskulær syk- } \\
\text { dom (særlig høyre side) }\end{array}$ \\
\hline Antidepressiver & Amfetamin & Cushings syndrom & Demens \\
\hline Benzodiazepiner & Ecstasy & Elektrolyttforstyrrelse & Encefalitt \\
\hline Captopril & Kokain & Hypertyreose & Hivinfeksjon \\
\hline Enalapril & Metamfetamin & Influensa & Huntingtons sykdom \\
\hline Østrogen & & Uremi & Nevrosyfilis \\
\hline Kalsium & & Vitaminmangel ( $\mathrm{B}_{12}$, niacin) & Sydenhams chorea \\
\hline Levodopa & & & Traumatisk hjerneskade \\
\hline Litiumoverdosering & & & Tourettes syndrom \\
\hline Seponering av steroider & & & Tumor cerebri \\
\hline Steroider & & & Wilsons sykdom \\
\hline Sympatikomimetika & & & \\
\hline
\end{tabular}

trettheten. Etter utskrivningen er hun blitt fulgt opp av psykisk helsevern og har hatt en innleggelse $i$ distriktspsykiatrisk senter. Årsaken til innleggelsen var mistanke om depresjon, som ikke lot seg bekrefte. Men pasienten var sliten pga. stor arbeidsbelastning og hun fikk et kort avlastningsopphold.

Ved siste kontroll, vel fire måneder etter første innleggelse, virket det som om pasienten mestret sin livssituasjon. Hun slet fortsatt med ettervirkninger av borreliosen i form av hodepine og tretthet, men var i bedring.

Diagnosen sikker nevroborreliose baseres på kliniske nevrologiske symptomer ledsaget av at det i cerebrospinalvæsken er forhøyet antall leukocytter og positiv borreliaantistoffindeks. Hos vår pasient ble mistanken om nevroborreliose opprettholdt i tidlig fase og behandingen fullført selv om antistoffindeksen var negativ i de to første cerebrospinalvæskeundersøkelsene. Diagnosen ble bekreftet etter to måneder, da antistoffindeksen var blitt positiv. Antistoffresponsen er ofte forsinket ved borreliainfeksjoner (2). I tidlig fase av nevroborreliose (symptomvarighet under seks uker) er antistoffindeks negativ hos ca. $26 \%$, og serum kan også være antistoffnegativ. Vår pasient ble nærmest symptomfri etter antibiotikabehandlingen, men merket etter hvert redusert arbeidskapasitet og tretthet. Det ble mistenkt residiv av infeksjonen, men normalt celletall i cerebrospinalvæsken avkreftet dette. Tilstedeværelse av antistoffer alene tyder ikke på aktiv infeksjon. Det er nylig vist at ca. $50 \%$ plages av tretthet 30 måneder etter behandlet nevroborreliose (3).

\section{Diskusjon}

Mani er en sykelig tilstand som kjennetegnes av hevet stemningsleie og økt fysisk og psykisk aktivitet. Stemningsleiet harmonerer ikke med pasientens situasjon og kan variere fra bekymringsløs jovialitet til ukontrollerbar oppstemthet. Oppstemtheten ledsages av økt energi som fører til overaktivitet, taleflom og ned- satt søvnbehov. Oppmerksomheten kan ikke holdes fast, og personen lar seg lett distrahere. Selvfølelsen er ofte økt, med grandiositet og overdreven selvtillit. Tap av normale sosiale hemninger kan føre til atferd som er lettsindig, dumdristig eller upassende og utypisk for personen. Mani kan forveksles med delirium - en forvirringstilstand som kjennetegnes av akutt debut, desorientering, visuelle hallusinasjoner og svingende bevissthetsnivå (4).

Mani er ofte ledd i bipolar lidelse (primær mani), men kan ha mange andre årsaker (sekundær mani). Livstidsprevalensen av primær mani er $1 \%$ (5). Prevalensen av sekundær mani er langt vanskeligere å angi pga. stor variasjon i ulike subgrupper. Sekundær mani kan blant annet skyldes medikamenter, rusmidler, metabolske forstyrrelser eller nevrologisk sykdom (tab 2) (6). А identifisere sekundær mani kan være vanskelig. Høy alder og somatiske symptomer tilsier skjerpet mistanke. Eldre voksne er i faresonen på grunn av øt forekomst av medisinske og nevrologiske sykdommer. Mani hos eldre blir ofte feildiagnostisert som demens med agitasjon (7).

Det er verdt å merke seg at mani og andre psykiatriske symptomer kan skyldes nevrologisk sykdom selv om bildefremstilling av hjernen (CT, SPECT og MR), elektroencefalografi (EEG) og blodprøver er normale. Dette forsterker behovet for en grundig nevrologisk undersøkelse, inklusive analyse av spinalvæske, i en tidlig fase. Spinalvæskeundersøkelser kan være nyttig for å identifisere infeksjon (nevroborreliose, nevrosyfilis, virus og andre infeksiøse agens som kan gi encefalitt), karsinomatose, autoimune sykdommer og enkelte nevrodegenerative sykdommer (demens, Creutzfeldt-Jakobs sykdom) (8).

Lyme-borreliose er en flåttbåren infeksjon forårsaket av spiralbakterien Borrelia burgdorferi. Sykdommen kan være lokalisert til hud (erythema migrans) eller disseminert til andre organsystemer, hvorav nervesystemet er vanligst. De fleste tilfeller av disseminert sykdom som er meldt inn til Meldingssystem for smittsomme sykdom- mer (MSIS), kommer fra Agderfylkene, Vestfold, Telemark, Sogn og Fjordane og Møre og Romsdal, men det er også rapportert tilfeller lenger nord i landet (8).

Borreliainfeksjon i nervesystemet (nevroborreliose) kan gi opphav til en rekke ulike symptomer som alle ledsages av forhøyet antall mononuklære leukocytter i cerebrospinalvæsken (7). De vanligste symptomene er smerter (lokalisert til nakke, rygg, bryst, abdomen eller ekstremiteter) pga. meningoradikulitt og facialisparese. Infeksjonen kan i sjeldne tilfeller ramme sentralnervesystemet og gi forvirring, tremor og andre ufrivillige bevegelser, ustøhet, halvsidige lammelser, afasi og psykose. Diagnosen nevroborreliose baseres på tilstedeværelse av nevrologiske symptomer kombinert med at det samtidig i cerebrospinalvæsken er forhøyet antall lymfocytter og borreliaantistoffproduksjon påvist ved høy ratio mellom nivåene i spinalvæske og serum (også kalt positiv antistoffindeks). Antistoffindeks i cerebrospinalvæsken er imidlertid negativ hos ca. $26 \%$ i tidlig fase (symptomvarighet under seks uker), og serum kan også være antistoffnegativ (9). Under halvparten har sikker sykehistorie med flåttbitt eller erythema migrans. Behandling med antibiotika gir rask symptomlindring og bør startes så snart man har klinisk mistanke om nevroborreliose og finner høyt antall lymfocytter i spinalvæsken. Lang tid fra symptomdebut til behandling er assosiert med økt frekvens av langtidsplager $(3,10)$. Doksycyklintabletter $200 \mathrm{mg}$ daglig i 14 dager er like effektivt som intravenøs ceftriakson ved affeksjon av det perifere nervesystemet (facialisparese og meningoencefalitt), men ved encefalitt vil mange anbefale intravenøs ceftriakson $2 \mathrm{~g}$ daglig i 14 dager (11).

Vår pasient hadde mani forårsaket av borreliaencefalitt. Det er beskrevet forskjellige psykiatriske symptomer ved nevroborreliose $(12,13)$, men debut av manisk sykdomsbilde er ikke tidligere beskrevet $\mathrm{i}$ Europa. I en kasuistikk fra Nord-Amerika beskrives en pasient som utviklet et bipolarliknende syndrom med både depresjon og mani som første symptom på borreliainfeksjon (14). De mange manifestasjonene av nevroborreliose tilsier at man bør vurdere den som en aktuell differensialdiagnose og undersøke cerebrospinalvæsken ved første manifestasjon av psykotisk lidelse, særlig når den er ledsaget av smerter.

\section{Konklusjon}

Ved nyoppstått psykose, inkludert mani, bør man ha nevrologisk årsak i tankene selv om bildefremstilling av hjernen og blodprøver er normale. Nevroborreliose og andre encefalitter diagnostiseres ved spinalvæskeundersøkelser, og raskt innsatt behandling bedrer prognosen.

Pasienten har gitt samtykke til at artikkelen blir publisert. 


\section{Adrian Razvan Pasareanu (f. 1974)}

er assistentlege ved Distriktspsykiatrisk senter Solvang, Sørlandet sykehus

Forfatter har fylt ut ICMJE-skjemaet og oppgir ingen interessekonflikter.

\section{Åse Mygland (f. 1958)}

er spesialist i nevrologi og overlege ved Nevrologisk avdeling og Avdeling for voksenhabilitering, Sørlandet sykehus Kristiansand og professor II ved Institutt for klinisk medisin, Universitetet i Bergen

Forfatter har fylt ut ICMJE-skjemaet og oppgir ingen interessekonflikter.

\section{Øistein Kristensen (f. 1945)}

er spesialist i psykiatri og overlege ved Avdeling for rus og avhengighetsbehandling, Sørlandet sykehus Kristiansand

Forfatter har fylt ut ICMJE-skjemaet og oppgir ingen interessekonflikter.
Litteratur

1. World Health Organization. The ICD-10 Classifica tion of mental and behavioural disorders. Clinical descriptions and diagnostic guidelines. Genève: World Health Organization, 1992.

2. Ljøstad U, Skarpaas T, Mygland A. Clinical usefulness of intrathecal antibody testing in acute Lyme neuroborreliosis. Eur J Neurol 2007; 14: 873-6.

3. Eikeland R, Mygland A, Herlofson K et al. European neuroborreliosis: quality of life 30 months after treatment. Acta Neurol Scand 2011; 124: 349-54.

4. Malt UF, Retterstøl N, Dahl AA. Lærebok i psykiatri. Oslo: Gyldendal Akademisk, 2005

5. Merikangas KR, Akiskal HS, Angst J et al. Lifetime and 12-month prevalence of bipolar spectrum disorder in the National Comorbidity Survey replication. Arch Gen Psychiatry 2007; 64: 543-52.

6. McDonald WM. Epidemiology, etiology, and treatment of geriatric mania. J Clin Psychiatry 2000; 61 (Suppl 13): 3-11.

7. Brooks JO 3rd, Hoblyn JC. Secondary mania in older adults. Am J Psychiatry 2005; 162: 2033-8.

8. Deisenhammer F, Egg R, Giovannoni $G$ et al. EFNS guidelines on disease-specific CSF investigations. Eur J Neurol 2009; 16: 760-70.

9. Folkehelseinstituttet. MSIS-statistikk www.msis.no (1.6.2011)

10. Ljøstad U, Mygland A. Remaining complaints 1 year after treatment for acute Lyme neuroborre- liosis: frequency, pattern and risk factors. Eur J Neurol 2010; 17: 118-23.

11. Mygland $\AA$, Ljøstad U, Fingerle $V$ et al. EFNS guidelines on the diagnosis and management of European Lyme neuroborreliosis. Eur J Neurol 2010; 17: 8-16, e1-4

12. Fallon BA, Kochevar JM, Gaito A et al. The under diagnosis of neuropsychiatric Lyme disease in children and adults. Psychiatr Clin North Am 1998, 21: 693-703, viii.

13. Markeljevic J, Sarac H, Rados M. Tremor, seizures and psychosis as presenting symptoms in a patient with chronic lyme neuroborreliosis (LNB). Coll Antropol 2011: 35 (suppl 1): 313-8.

14. Fallon BA, Nields JA, Parsons B et al. Psychiatric manifestations of Lyme boreliosis. J Clin Psychiatry 1993; $54: 263-8$

Mottatt 10.6. 2011, første revisjon innsendt 16.9. 2011, godkjent 29.9. 2011. Medisinsk redaktør Erlend Aasheim.

\section{Kommentar}

\section{Krevende diagnostikk - viktig diagnose}

Det er lite sannsynlig at en frisk pasient som ikke tidligere har hatt psykiatriske problemer, blir manisk i slutten av 50-årsalderen uten at det er et organisk grunnlag for det.

Den somatiske diagnostikken kan være krevende. Det er nødvendig å utrede mulige nevrologiske, metabolske, medikamentelle og rusmiddelrelaterte årsaker. Pasienten hadde tidlig symptomer som redusert kraft og ustø gange som pekte i nevrologisk retning. Mange tilstander vises ikke ved CT, og noe sjeldnere heller ikke ved MR. Spinalpunksjon bør foretas tidlig.

Antistoffutviklingen ved borreliose er sen, og negativ serologisk prøve er hyppig, særlig tidlig i sykdomsfasen (1). Inkubasjonstiden kan være lang, slik at pasienten i mange tilfeller ikke er kjent med eksponering. De diagnostiske utfordringene kan illustreres ved at sykdommen også kalles «den nye store sykdomsimitatoren». Nevroborreliose er blitt den hyppigste nevroinfeksiøse tilstanden i Europa der smittekilden er en vektor (2). Forekomsten er økende, noe som trolig henger sammen med endret vegetasjon og mildere klima.

De vanligste psykiatriske symptomene er tretthet og depresjon, men panikkanfall, schizofreniliknende symptomer og hallusinasjoner kan også forekomme (2).

Pasienten ble innlagt to måneder senere med mistanke om depresjon, men diagnosen ble ikke bekreftet. Derimot var hun preget av tretthet, som er en vanlig følgetilstand som kan vare lenge. Det er også påvist regional hypoaktivitet med hensyn til blodforsyning og metabolisme, særlig i temporalog parietallappene og i det limbiske system etter gjennomgått behandling (3).

I tillegg til nevrologiske og psykiatriske symptomer er særlig hudmanifestasjoner vanlige, men også hjerte og ledd kan affiseres.

Selv om prognosen vanligvis er god, kan en snikende utvikling medføre at flere hjerneområder kan bli affisert før diagnose og behandling, med protrahert forløp som følge.

Behandlingen kan være vanskelig fordi bakterien har utviklet mange forsvarsmekanismer. Behandlingen er ofte vellykket hvis man kommer tidlig til, men kronisk infeksjon kan være vanskelig å behandle (1).

Det er viktig med tidlig diagnose og behandling, både for å forkorte den aktive sykdommen og å forkorte restitusjonstiden. Siden symptombildet kan være så varierende, er det nyttig at også sjeldne tilfeller, som dette, blir publisert.

\section{Øivind Ekeberg}

oivind.ekeberg@ous-hf.no

Akuttmedisinsk avdeling

Oslo universitetssykehus, Ullevål

Øivind Ekeberg (f. 1945) er spesialist i psykiatri og veileder i psykodynamisk psykoterapi, er overlege i psykiatri, Akuttmedisinsk avdeling, Oslo universitettsykehus, Ullevål og professor II i medisinske atferdsfag, Institutt for medisinske basalfag. Universitetet i Oslo. Han arbeider klinisk og forskningsmessig særlig med selvmordsatferd, psykotraumatologi og psykiske reaksjoner ved somatisk sykdom.

Forfatter har fylt ut ICMJE-skjemaet og oppgir ingen interessekonflikter.

\section{Litteratur}

1. Brorson $\emptyset$. Borrelia burgdorferi - en unik bakterie. Tidsskr Nor Legeforen 2009: 129: 2114-7.

2. Bär KJ, Jochum T, Häger F et al. Painful hallucinations and somatic delusions in a patient with the possible diagnosis of neuroborreliosis. Clin J Pain 2005: 21: 362-3.

3. Fallon BA, Lipkin RB, Corbera KM et al. Regional cerebral blood flow and metabolic rate in persistent Lyme encephalopathy. Arch Gen Psychiatry 2009; 66: 554-63

Mottatt 30.10.2011 og godkjent 3.11.2011. Medisinsk redaktør Erlend Hem 